\title{
Екологічна тріада в спорті. Сучасний погляд
}

\author{
УДК 61.613.7.502 \\ О. І. Осадча, О. О. Павлова
}

Національний університет фізичної культури та спорту України, Київ, Україна

\begin{abstract}
Резюме. У загальному плані поняття «екологія» прийнято розглядати як взаємодію організму з навколишнім середовищем і вплив різних сприятливих і несприятливих патогенних факторів середовища на життєдіяльність організму, на підтримання або порушення процесів життєзабезпечення і функціонування систем гомеостазу й організму в цілому. Мета. Узагальнення думок щодо взаємодії між екологічним станом навколишнього середовища та формуванням сталого розвитку спортсмена. Методи. Аналіз та узагальнення науково-методичної літератури. Результати. Навколишнє середовище відіграє значну роль у фізичному, психічному і соціальному добробуті людини. Складні взаємозв'язки між факторами навколишнього середовища та здоров'ям людини слід розглядати в більш широкому просторовому, соціально-економічному і культурному контексті, особливо на сучасному етапі розвитку суспільства.
\end{abstract}

Ключові слова: екологія, екологічне середовище, екологічні фактори, фізичне виховання.

\section{Ecological triad in sport. Modern view \\ O. I. Osadcha, O. O. Pavlova}

National University of Physical Education and Sport of Ukraine, Kyiv, Ukraine

\begin{abstract}
In general, the concept of "ecology" is considered as the interaction of the body with the environment and the influence of various favorable and unfavorable pathogenic factors on the body vital functions, maintenance or disruption of life support and functioning of homeostasis and the body as a whole. Objective. Generalization of opinions on the interaction between the ecological state of the environment and the formation of sustainable development of the athlete. Methods. Analysis and generalization of scientific and methodological literature. Results. The environment plays a significant role in human physical, mental and social well-being. The complex relationship between environmental factors and human health should be considered in a broader spatial, socioeconomic and cultural context, especially at the present stage of society development.
\end{abstract}

Keywords: ecology, ecological environment, ecological factors, physical education.

Постановка проблеми. Взаємозв'язок між природою і суспільством сьогодні стає об'єктом пильної уваги науки і широкої громадськості. Ця проблема набула гострого соціального звучання, актуальність якого зростає з кожним роком $[2,3]$.

У загальному плані поняття «екологія» прийнято розглядати як взаємодію організму з навколишнім середовищем і вплив різних сприятливих i несприятливих патогенних фракторів середовища на життєдіяльність організму, на підтримання або порушення процесів життєза- безпечення і функціонування систем гомеостазу й організму в цілому [2, 3, 6].

Негативні екологічні впливи численні, але основними $\epsilon$ фрізико-хімічні та біологічні фрактори забруднення середовища, нейропсихогенний вплив і їх спільний вплив на фрізичний стан організму, функціонування його окремих органів i систем, адаптогенні можливості, активність, рухливість, витривалість, працездатність $[4,7,8]$.

Як фундаментальний соціальний фактор спорт разом з політикою, економікою і культу- 
рою $є$ дуже важливим. Навколишнє середовище відіграє значну роль у фрізичному, психічному і соціальному добробуті людини. Складні взаємозв'язки між фракторами навколишнього середовища та здоров'ям людини слід розглядати в більш широкому просторовому, соціальноекономічному і культурному контексті [1-4].

Фізічна культура $\epsilon$ провідним фрактором здорового способу життя, а також його наслідком. Як бачимо, це поняття досить широке, об'єднуючи в собі причину і наслідок, воно виступає в особливій якості, іменованій «фрізична культура» [1, 3, 5, 9].

Фізична культура має чотири основні форми:

- фрізичне виховання і фрізична підготовка до конкретної діяльності (професійно-прикладна фрізична підготовка);

- відновлення здоров'я або втрачених сил засобами фрізичної культури - реабілітація;

- заняття фрізичними вправами з метою відпочинку - рекреація;

- найвище досягнення у сорері спорту.

Особливого значення під час занять спортом для досягнення високих результатів набувають наявність фрізичного стану організму, рівень тренованості, загальної та спеціальної фрізичної підготовки, адаптаційні можливості, працездатність і рівень витривалості атлета.

Багато видів спорту виникли завдяки соціально-екологічним зв'язкам, що пов'язано з місцем їх походження (гольф з Шотландії або серфінг з Полінезії).

Важливо визнати фундаментальні відносини, які спорт має з навколишнім середовищем. Всебічний аналіз природних процесів і узагальнення фундаментальних наукових знань про найбільш ефективне і раціональне використання природи в інтересах людства визначив необхідність фрормування нового комплексного наукового напряму - екологія спорту.

Мета дослідження - узагальнення поглядів на особливості взаємодії між екологічним станом навколишнього середовища та фрормуванням сталого розвитку спортсмена.

Методи дослідження: аналіз та узагальнення науково-методичної літератури.

Результати дослідження та їх обговорення. Під час аналізу літературних джерел було визначено структуру екологічної тріади, що впливає на спортивну діяльність, та визначено напрями зменшення негативного впливу цих факторів (рис. 1).

Екосистема - це вплив зовнішніх фракторів природного та антропогенного походження на людину, а саме: глобальне потепління; посилен-

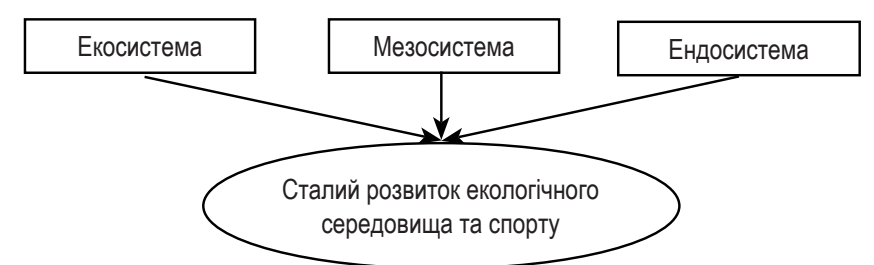

Рисунок 1 - Структура екологічної тріади в сучасному спорті

ня ультрафріолетового опромінення; зміна клімату, втрата біорізноманіття; накопичення важких металів у воді та ґрунті, викиди парникових газів.

Усе це може бути причиною захворювань та стресу, втрати місць для занять спортом. Непередбачувані й екстремальні погодні умови можуть створювати труднощі для занять спортом в цілому.

Безпосередньо виділяють так звані середовищні захворювання, що включають розділи біології, токсикології, епідеміології, генетичні фрактори, соціологічні чинники, токсикогенні ряду виробництв і профресійні патогенні фактори, які призводять до розвитку профресійної патології, що стосується і спортсменів профресійного рівня. Виявлення і оцінювання ступеня патогенних змін проводять на основі залежності «дозачас-ефект» і з урахуванням клітинних і молекулярних механізмів їх дії. Особливо враховують санітарно-гігієнічні умови, ризик використання ліків, вроджені анатомічні та фрізичні аномалії, виникнення онкологічних, алергічних, інфекційних, травматологічних (особливо в спорті), імуногормональних та інших захворювань.

Основні напрями зменшення негативного впливу екологічних фракторів:

- використання очисних споруд;

- зниження обсягів викидів парникових газів;

- збільшення зелених і рекреаційний зон для занять спортом.

Мезосистема - вплив значних спортивних змагань і спортивних споруд на екологічний стан навколишнього середовища. Одним 3 важливих завдань, яке необхідно вирішувати в мезосистемі, $\epsilon$ визначення «екологічного та вуглецевого сліду» спортивних змагань та споруд.

«Екологічний слід» - це інструмент обліку ресурсів, що дозволяє побічно виміряти глобальний тиск на навколишнє середовище, пов'язаний з використанням його під час проведення спортивних подій.

«Вуглецевий слід» - показник викидів парникових газів в атмосферу під час проведення значних спортивних змагань та фрункціонування спортивних споруд.

Обидва сліди доповнюють один одного і допомагають зрозуміти вплив спортивної події або 
споруди на навколишнє середовище в цілому i щодо конкретних фракторів події.

Негативні мезоекологічні фрактори:

- руйнування екосистем;

- споживання великої кількості невідновлюваних природних ресурсів;

- забруднення ґрунту і водних ресурсів при використанні пестицидів та штучних покриттів;

- ерозії ґрунту під час будівництва спортивних об'єктів і від дії глядачів;

- утворення великої кількості відходів від спортивних об'єктів і вболівальників;

- основні напрями зменшення негативного впливу мезоекологічних чинників;

- ініціювання та підтримання екологічних послуг для операторів спортивних споруд;

- прив'язка фрінансування спортивних споруд до дотримання екологічних стандартів;

- включення екологічного менеджменту в роботу спортивних адміністрацій та операторів.

Ендосистема - стосунки з родиною, тренером, друзями, що мають безпосередній вплив на розвиток особистості спортсмена та фрормування екологічного сприйняття ним спортивної діяльності.

У спорті агресивним середовищем також $€$ наявність суперників (особливо в єдиноборствах і спортивних іграх), значні навантаження в боротьбі за призові місця, престиж, прагнення до рекордів або високих грошових призів.

Щодо негативних фракторів ендосистеми, слід відзначити рівень їх сприяння, що залежить як від еко- та мезосистем, так і від ставлення людини до загальних факторів ендосистеми.

За наявності патології порушуються і різко знижуються фрізичні якості, необхідні для досягнення високих результатів. Для успішних виступів у спорті потрібні такі якості, як швидкість, сила, координація, інтенсивність відновлення біохімічних зрушень і їх буфрерна ємність, стійкість імунної системи і гуморально-гормонального гомеостазу, психологічна стійкість і стабільність тощо. Особливо важливими є високий тип адаптації до підвищених фрізичних навантажень, ступінь еко-

\section{Література}

1. Иорданская ФА, Юдинцева МС. Мониторинг здоровья и функциональная подготовленность высококвалисиццированных спортсменов в процессе учебно-тренировочной работы и соревновательной деятельности [Monitoring of health and functional fitness of highly qualified athletes in the process of educational work and competitive activity]. Москва, 2006. $240 \mathrm{p}$.

2. Левин ЮМ. Эндоэкологическая медицина [Endoecological medicine]. Москва, 2002. 135 с.

3. Медведев ВМ, Пономарева АГ, Царев ВН. Методы эндоэкологической реабилитации с применением фитотерапии малых доз: учебное номічності фрункціонування кардіореспіраторної системи, рівень аеробної продуктивності, великий пульсовий резерв відновлення і нормотонічна реакція серцево-судинної системи після навантаження, високий ступінь компенсаторного виду адаптації.

Оскільки фрізіологічні системи і психоемоційні процеси визначають прямий і зворотний зв'язок із зовнішнім світом, то ендоекологія проявляється тими параметрами організму, які визначають характер і результат взаємодії зовнішніх фракторів із суб'єктом сприйняття. Адаптогенні можливості - це сума пристосувань організму до фракторів зовнішнього середовища. Життєдіяльність на клітинно-молекулярному рівні можна розглядати як ендоекологічний вплив на процеси метаболізму - життєзабезпечення. Подібна взаємодія і забезпечує в основному поняття «життєвої сили», психологічної, емоційної, фрізичної активності людини, що особливо проявляється у творчій і спортивній діяльності.

Фактори, що знижують життєво важливі функції організму, можна розглядати як несприятливі ендоекологічні передумови, що знижують адаптогенні можливості організму. На цій основі необхідно вирішувати проблеми індивідуалізації підготовки та тренування спортсменів, здійснювати підбір принципів і підходів індивідуального програмування спортивної діяльності на основі поглибленого індивідуального підходу, заснованого на комплексному вивченні здібностей і можливостей спортсмена і діапазону його функціональної активності і працездатності. Необхідним $\epsilon$ підбір ознак і якостей, які можуть сприяти досягненню високих спортивних результатів.

Висновки. Слід зазначити, що в екологічній тріаді велику роль відіграє людина. Вона $є$ ініціатором діяльності зі зменшення впливу цих фракторів. Екологія спорту - це побудова стосунків або контактів спорту та екологічного середовища, вплив особистості спортсмена на процеси, які забезпечують сталий розвиток з довгостроковим захистом природної основи життя.

пособие [Methods of endoecological rehabilitation using phytotherapy of small doses: teaching guide]. Москва, 2008. 73 p.

4. Пацерняк СА. Стресс, вегетозы, психосоматика. Stress, vegetative diseases, psychosomatics. SPb., 2002. 383 p.

5. Пономарева АГ, Медведев ВМ, Полтавская ЕЮ. Изменение физиологических показателей у спортсменов водного вида спорта под влиянием физических нагрузок и приема фиточая «Мономах» [Changes in physiological indices of water sports athletes under the influence of physical loads and the use of herbal tea «Monomakh»]. Традиционная медицина. 2010; № 3 (14): 4-56 
Спортивна медицина, фізична терапія та ерготерапія № 1, 2021

6. Серпер СА. Экология и спорт: особенности взаимосвязи в процессе обучения в вузе // [Ecology and sport: peculiarities of the relationship in the process of education at the university]. Азимут научных исследований: педагогика и психология 2019. № 2 (27): 218-220.

7. Осадчая ОИ, Футорний СМ, Шматова ОО, Маслова ОВ. Неблагоприятные экологические факторы как причина оксидантного стресса спортсменов велосипедистов-любителей [Unfavorable environmental factors as the cause of oxidative stress in amateur cyclists]. Науковий часопис Національного пед.університету ім. МП. Драгоманова. Серія № 15. 2018; 9(103)18: 65-69

osadchay1965@gmail.com

12olga1997.pavlova@gmail.com
8. Осадчая ОИ, Имас ЕВ, Футорний СМ, Шматова ОО, Маслова ОВ. Роль экологических неблагоприятных факторов в развитии патологических процессов у спортсменов-велосипедистов [The role of environmental unfavorable factors in the development of pathological processes in athletescyclists]. Спортивна медицина і фізична реабілітація. Нац. ун-т фіз. вих. і спорту України, Київ: Олімпійська літ. 2019; 1: 43-47.

9. Futornyi Serhii, Maslova Olena, Rychok Tatiyana, Hopey Maksym, Tarnavskiy Artur. Modern aspects of the ecological culture implementation in the physical education process of different population groups. Journal of Physical Education and Sport. 2020; 20: 348-353. 